\title{
Noel Polk
}

\section{How Shreve Gets in to Quentin's Pants}

The occasion for my title occurs in The Sound and the Fury just after Gerald Bland, his mother, Spoade, Shreve, and two veiled young ladies encounter Quentin Compson in the clutches of the law and of an angry brother who wants Quentin pilloried for molesting his sister, whom Quentin has ostensibly been helping to find her way home. Julio, the brother, is as certain of Quentin's intentions toward his sister as Quentin is certain of Dalton Ames's intentions toward his sister.

It's part of an extended tumultuous episode of two or three pages of which we haven't yet taken the full measure. When Shreve hears that Quentin is under arrest, he starts climbing out of Mrs. Bland's automobile, and Quentin notices that he is wearing "a pair of my flannel trousers, like a glove" (141). The final detail, the glove, argues pretty certainly how Quentin's tight flannels mould and magnify Shreve's genitals, and how conscious Quentin is of them. Quentin claims that he doesn't "remember forgetting the pants" when he packed his clothes earlier in the day for shipment home - "I didn't remember forgetting them" is an extremely curious, even paradoxical, way of describing his packing: it's almost a double negative which, like double negatives, always mean grammatically the opposite of what a user is trying to say. Quentin may thus mean that he remembers very well that Shreve has his pants, and in any case the phrasing seems to be a rhetorical ploy by means of which he can distance himself from the trousers and what they now contain, and from the question why they seem to be on Shreve and not on their way to Jefferson. We can also tell something of the pants' impact on Quentin at this moment by his almost instantaneous deflection to Mrs Bland's double chins, which he also claims to have forgotten, and, more importantly, to the two pretty girls also in the car who, though they are veiled, he believes regard him "with a kind of delicate horror" (141). Quentin forces his attention from exposed male sexuality to the double chins of a voyeuristic and pandering mother and then, finally, to the veiled heterosexual threat that the two girls represent. He may, of course, feel that they look on him with horror simply because they know that he's under arrest, but the impact on him, at this moment, of Shreve in his pants allows us to speculate that their horror, delicate or not, is, in Quentin's imagination, grounded in his fear that they somehow intuitively know he is queer maybe, he thinks, they have caught him looking at Shreve's genitals - and that their "delicate horror" is more nearly disgust. The girls' names - Miss Holmes and Miss 
Daingerfield - resonate thematically, indicting Quentin's own home and, by implication, heterosexual union: home, as Quentin has reason to know, is a dangerous place.

From a view outside his head, the ensuing scene is a broadly comic one, a kind of antic slapstick, a parade worthy of The Keystone Cops or Fellini. Looked at through Quentin's eyes, however, the scene is a dark tableau of all the sexual baggage he has brought to Cambridge from Mississippi. Quentin drags with him to the Squire who is to decide his case a network of characters who represent the array of his pathologies: Gerald and his mother, in an oedipal relationship that grotesquely parodies the murky oedipal issues in his own family; Miss Holmes and Miss Daingerfield; Shreve, whom Spoade calls his "husband"; an astonishing group of naked and half-naked boys who emerge from the surrounding shrubbery and woods almost like an hallucination; an angry brother who also wants to defend and control his sister's virginity; and, finally, the little girl herself, whom Quentin calls "little Sister," and who may be, in some way, Caddy's own young unsexual, pre-sexual, self, the Caddy that Quentin claims to want to preserve. Quentin drags all of these horrors to the judgment seat with him - a temporal judgment seat that foreshadows that ultimate Judgment Seat, which he anticipates seeing in the not very distant future.

This portion of the scene follows a complex narrative orchestration of Quentin's past and present which braids together three different plots: the one involving Quentin and the little Italian girl; the one in which Quentin at first alone and then with the lost girl in tow, encounters the boys first when they are fishing and then at the mill where they are skinny-dipping; woven throughout the scene is Quentin's simultaneous memory of his sexual play as a child with Natalie in the barn in the rain, which Caddy interrupts. Quentin and Natalie are playing something like doctor in the barn, touching each other. Caddy's intervention turns the scene into a tempest of guilt and shame and retribution that ends when Quentin throws himself into the pig's wallow and then smears it all over Caddy. Fuguing in and out of that powerful memory of childhood innocence turned corrupt are Quentin's two encounters with the boys. Does the intertwining of the memory of Natalie with his attempts to help the little Italian girl find her way home allow us to wonder how pure Quentin's motives are - one aborted, perhaps abortive, youthful heterosexual encounter to be replaced by another with perhaps different results by which Quentin could establish his heterosexuality? Does he want, at any level, to play doctor with his present little sister? Perhaps. He is interrupted this time too - not by Caddy but by the girl's brother, who stops him from what Spoade later jokingly calls Quentin's "nefarious purposes."

At the first encounter, Quentin and the fishing boys banter pleasantly enough. They aren't catching anything, though, and Quentin overhears one propose that they go to the 
mill to go swimming (122). I think it no accident of Quentin's peregrinations that he heads directly for the mill, with the little girl in tow, whose presence at the mill pond spoils the boys' homosocial eden, though Quentin tries to assure them that "she's just a girl. She can't hurt you." Perhaps Quentin drags her there to veil his truly nefarious purposes, to get a look at the naked bodies of these boys. He is, recall, throughout, hyper-conscious of male bodies. Perhaps, too, he drags her there precisely to grant himself the interruption that Caddy had provided in the earlier scene.

If Quentin follows the boys to the pond to see them naked, he sees more than he bargains for. As the scene nears its climax, Quentin suddenly sees "him coming up the path running" (139, my italics) but does not identify the "him." Then he sees "another man, an oldish man running heavily, clutching a stick, and a boy naked from the waist up, clutching his pants as he ran." "There's Julio," says the little girl, but we dont know which male she is referring to. The initial "him" that Quentin sees might of course be Julio, but we would expect Julio to be with the sheriff, who is clearly the other man. The other "boy, naked from the waist up and clutching his pants" as he runs, is clearly not Julio, since when Julio jumps on Quentin, the "half naked boy" begins "darting and jumping up and down... clutching his trousers." Further, the appearance of the sheriff and the "boy" in the same sentence may suggest that they are or have been "together" while the boy was naked. In the same sentence Quentin also notes and juxtaposes with the boy and the sheriff another astonishing figure: he sees "another stark naked figure come around the tranquil bend in the path running and change direction in midstride and leap into the woods, a couple of garments rigid as boards behind it." Apparently the halfnaked boys are the fishing, skinny-dipping boys just out of the mill pond: Julio has queried them about his sister, been told which direction she and Quentin went, and taken off with Anse in pursuit; they get out, grab their clothes and try to dress while running so as not to miss anything; some don't quite get fully dressed. These boys, then, are avenging homoerotic furies, interrupting Quentin's heterosexual idyll with the Italian girl as Caddy had interrupted his play with Natalie; both Caddy and the boys and Julio and the sheriff may drastically overestimate what Quentin's nefarious purposes are: but they may not. What's important, it seems to me, is what registers most potently on Quentin as this astonishing series of events takes place, including Anse's twice-noted phallic "stick" and the phallic "garments rigid as boards" which follow the latest naked boy into the woods. At the very least, if Quentin goes to the mill to see the boys skinny-dipping, he gets what he wants, in spades. These boys represent Quentin's suppressed homoerotic desires chasing him relentlessly and even bringing with them, as if to remind him how dangerous they are, the sheriff - the superego, the simultaneous agent of repression of that forbidden desire. The scene is a maelstrom of the homoerotic and of its possible 
consequences: Miss Holmes and Miss Daingerfield, veiled, look on him with a kind of "delicate horror," but that's certainly mild compared to the horror and loathing with which he certainly regards himself in such moments when the homoerotic descends upon him so publicly and so menacingly - and, given the police and the judge, so judgmentally.

During the scene that leads to Quentin's pathetic fight with Gerald Bland Quentin twice turns, shifts so as to repudiate Shreve's hand so publicly upon his knee. Moments like these provide us with a slightly different context against which to view two or three other passages in Quentin's section. The first occurs in the section's earliest pages. Looking out the window of his Harvard dormitory room, Quentin watches the helterskelter rushing of students on their way to class. Spoade emerges from the crowd and disrupts Quentin's meditations, throws his poetic description of the scene, his elegant parallel structures and his compound and complex sentences, into a syntactical and sexual chaos: “....and Spoade. Calling Shreve my husband. Ah let him alone, Shreve said, if he's got better sense than to chase after the little dirty sluts, whose business?" Quentin immediately deflects his thoughts toward the problem of his virginity as a heterosexual, about which he agonizes much throughout the day. At the end of the paragraph, however, he reverts to the homoerotic, repeating again Shreve's suggestion that homosexuality is better than "chasing after the little dirty sluts," before remembering his response: "Did you ever have a sister? Did you? Did you?" (78). Since these words later precede Quentin's attack on Gerald Bland, we may suppose that Quentin's defense of Caddy's maidenhead is at least in part a denial of the homosexual: he is angry because Gerald can get laid in the right and proper normal way and he, Quentin, cannot.

Several things interest us here. First is the absolute crumbling of Quentin's syntax here and elsewhere, especially when the twin stalkers of the homoerotic and the heteroerotic collide and unmoor him from the grammar by which he maintains control over his disintegrating psyche. When he is most in control, his syntax is elegant, complex, beautiful; when he loses control of his thoughts, syntax more or less goes out the window and his thoughts turn to chaos; you will remember that toward the end of his section, he loses complete control even of capitalization and punctuation, and in the penultimate paragraph of his section, the final conversation with his father, he loses even the capitalized "I," which has been a kind of totem ego for him. The syntactical breakdown when Spoade emerges into his vision suggests that Spoade really emerges from some undeniable claim on his deepest desires. Quentin immediately connects Spoade with what is so obviously a problematic relationship with Shreve. The recalled scene, especially Spoade's banter with Shreve about the dirty little sluts, might argue that there is something relatively open, at least among them, about the homoerotic (perhaps they live in a sort of homosexual com- 
munity), but we can't tell how much of a wife Quentin is to Shreve, and of course Shreve and Spoade may be merely teasing Quentin about his inability to lose his virginity, which a real man would have lost long before reaching Quentin's age - or he would at least lie about it. Quentin seems to have been unable either to lose it or to lie.

Other scenes, briefly: watching Gerald Bland row the skull, Quentin meditates on Gerald's mother's braggadocio about Gerald's success with women. Mrs. Bland likes him, Quentin, he thinks, because he is at least a Southerner, but she doesn't like Spoade, "since she met [him] coming out of chapel one He said she couldn't be a lady no lady would be out at that hour" (91). Again Quentin's syntax breaks down. Most authors would have put a dash between "one" and "He" to indicate an interrupted thought, but not Faulkner; the lack of such punctuation may indicate how smoothly Quentin corrects his thoughts as they head in that forbidden direction, which would reveal why Spoade was in fact in the chapel at such a late hour, and perhaps why Mrs. Bland is out so late. I suspect neither was there to worship. University chapels have always been notorious as homosexual gathering places, and that I suspect is what Quentin refuses to acknowledge; if Spoade has been there for a homosexual tryst, we may easily imagine a ménage-a-trois of Spoade, Shreve, and Quentin. Why Mrs. Bland is out that late at night is not clear either, but it's easy to speculate that she is checking up on the boys that Gerald is hanging out with; perhaps she's suspicious of Gerald's sexual preferences and that is why she all but pimps for him with girls. What Quentin suppresses here may also help explain why Mrs. Bland goes to the proctor to have Quentin moved out of Shreve's quarters (106): she wants to protect Quentin - and Gerald - from that homosexual element.

One final passage is worth a word or two. Quentin's remembered discussion with his father about women, which occurs just after he and the little Italian girl leave the bread shop, and a garbled memory of his discussion with Caddy about her pregnancy, her "sickness":

Because women so delicate so mysterious Father said. Delicate equilibrium of periodical filth between two moons balanced. Moons he said full and yellow as harvest moons her hips thighs. Outside outside of them always but. Yellow. Feet soles with walking like. Then know that some man that all those mysterious and imperious concealed. With all that inside of them shapes an outward suavity waiting for a touch to. Liquid putrefaction like drowned things floating like pale rubber flabbily filled getting the odor of honeysuckles all mixed up. (128)

This passage, one of the several most oft-quoted and uneasily commented upon in all of Faulkner, may lie at the root of all Quentin's problems. Recall that Quentin reports on 
two or three occasions arguments during which his father accuses his mother of setting Jason to spy on Caddy and Dalton Ames. Quentin gets accused of spying too, but denies it vehemently; this passage gives us reason to doubt those denials. I propose that here Quentin remembers seeing Caddy and Dalton Ames having sex. Again syntax fails him: but we may make some sense of the passage - the vision of "feet soles with walking like" suggest that he watched from a position where he could see their feet, Caddy's pointing upward, Dalton's between them pointing downward, and all four sort of walking and moving "like" - Quentin begins a simile, but words, comparisons, simply fail him. Father has filled him with disgust for sex, women, the monthly cycle of "periodical filth." Female genitals shaped "suavely" need only a touch to turn them to putrefied liquid; men are always "outside outside" but always want to get inside inside. His final vision combines a semen-filled condom - "drowned things floating like pale rubber flabbily filled [with semen]" - and the honeysuckle, which connection is why he forever is suffocated by the smell of honeysuckle.

This is a Freudian primal scene, a child's first vision of parental intercourse, and the beginning of Oedipal dynamics in a child's development, presented here with substitutions as such scenes nearly always are in Faulkner. In Freud, the Oedipus complex always involves an element of the homoerotic - the viewing child wants to replace both mom and dad in coitus, but associates the act with shame and, if discovered watching, with increased guilt that demands punishment. Dalton dominates Quentin's voyeuristic memory of Caddy and Dalton together, not Caddy. In his quieter, more intimate moments, he allows himself to fondle Dalton's name, repeating it several times in triads, almost like a chant, a love song, caressing his face as much as words can: "'Dalton Ames. Dalton Ames. Dalton Shirts. I thought all the time they were khaki, army issue khaki, until I saw they were of heavy Chinese silk or finest flannel because they made his face so brown his eyes so blue. Dalton Ames"' (92). He's got a crush on Dalton Ames that he cannot claim: and incest, horrible as it is, is more acceptable than homosexuality. Quentin's pathologies in his family are clear: his father's lugubrious, viscous attitudes toward women; his constant whining about his weak position in his family vis-à-vis his brother-in-law; Quentin's mother's whining about everything, while appearing always so seductively in or ready for bed: nothing in Quentin's home can have given him a very healthy model for marriage or heterosexual union; the only models are indeed quite terrifying ones. But neither has anything given him permission to pursue the homosexual. $\mathrm{He}$ is a man without a sexual option to give him the identity that he so clearly craves.

I hasten to add, in closing, that nothing I've said here today purports to argue that Quentin is a practicing homosexual; there is no such evidence, but only this galaxy of troubling evidence that at very least suggests how deeply the homoerotic urge and the 
fear of homosexuality have attached themselves to his sensibilities and sensitivities, and how awful it is to feel pulled in that direction when his culture and his family assumes heterosexuality, problematic though it be, as the right and proper end of a man. I'd suggest too the ontological dimensions of Quentin's dilemma: the possibility that he is homosexual and that he sees that as his only option works toward his decision to commit suicide much more profoundly than anything else that has been suggested. He wants desperately to not be a heterosexual virgin, but simply can't do it, as he puts it in this anguished passage:

....and I thought about how I'd thought about I could not be a virgin, with so many of them walking along in the shadows and whispering with their soft girlvoices lingering in the shadowy places and the words coming out and perfume and eyes you could feel not see, but if it was that simple to do it wouldn't be anything and if it wasn't anything what was I... (147)

In his mind, in his culture, a boy who can't get properly laid with so many available girls around, is just plain queer: and he cannot be that - or, as it turns out, anything else.

To a certain extent, of course, Shreve's literally wearing Quentin's pants is a Faulknerian joke, of a piece with the one that drives the present-day narrative of the Benjy section: Luster's dogged determination to find a golf ball that he can sell to a golfer for a quarter and go to the show. My friend Tom McHaney suggested long ago that not just Luster but all males in The Sound and the Fury are searching for lost balls. But neither joke is really as funny as it seems, is it? Shreve might not be in Quentin's pants, but he's surely in his head - a far more terrifying place for him to be.

WORK CITED

Faulkner, William. The Sound and the Fury. 1929. New Corrected Edition. New York: Random House, 1984. 